\title{
The Practice of Identity Politics Carried Out By Ex-Lepers
}

\author{
Ali Imron ${ }^{1, *}$, Siti Maizul Habibah ${ }^{2}$, Putri Indatus ${ }^{3}$ \\ ${ }^{1}$ Social Science Education, University State of Surabaya, Surabaya, Indonesia \\ ${ }^{2}$ Pancasila and Civic Education, University State of Surabaya, Surabaya, Indonesia \\ ${ }^{3}$ Mojokerto, Indonesia \\ *Corresponding author. Email: aliimron@unesa.ac.id
}

\begin{abstract}
Negative stigma on ex-lepers appears along with the constructed stigma in a society that considers leprosy as a contagious, incurable, hereditary disease, the curse of God, unclean, and causes disability. This constructed stigma affects ex-lepers to gain access to public services, such as health, education, and employment. Low accessibility to public services makes the ex-lepers subaltern groups in the social structure. Subaltern groups are characterized by oppression and discrimination to be marginalized. Subaltern closely related to the power of relations and politics, where the minority would be marginalized from the strong influence of society. These conditions affect them to have a turning point to fight to seek their obsession to be recognized and equalized through identity politics. Identity politics tend to put the interests of the members of the group in the front because they have the same identity or characteristics. Various forms of identity politics practice are realized through morality resistance and radical resistance. Subaltern utilizes speaking foras a representative and liaison for the group aspirations. The practice of identity politics is carried out by ex-lepers in Sumberglagah hamlet as tangible evidence to create equality of social representation.
\end{abstract}

Keywords: identity politics, subaltern, speaking for, resistance, equality

\section{INTRODUCTION}

The majority of infectious diseases occurred in developing countries that have a low socio-economic condition, one of which is leprosy. Leprosy is still feared by the people and even by some health workers. This is due to a lack of knowledge, understanding, and the erroneous belief toward leprosy and disabilities caused. Leprosy is a chronic infectious disease caused by the bacterium Mycobacterium leprae. In East Java, $30 \%$ of populations suffer from this disease which spread in 38 districts/cities with prevalence above 1.43 per 10,000 population. Nationally, East Java was ranked first in the number of lepers enrolled. While at the world level, Indonesia has become the third state contributor lepers for 17,012 lepers, after India for 126,800 lepers, and Brazil for 34,894 lepers.

After undergoing a long process of treatment and taking a long time, ex-lepers become disabled, because they are considered as disabled dysfunctional organs. Negative stigma on ex-lepers that considers leprosy is contagious, incurable, hereditary diseases, the curse of God, unclean, and cause disability.

As the case in Makassar, a leadership workshop for exlepers at Hotel Valentino on Dr. Sutomo Street, Makassar, South Sulawesi, was disbanded by the hotel management because it was considered disturbing the comfort of other guests. The hotel claimed to get complaints from other guests because of the ex-lepers who were on the sixth floor of the hotel. From the observation at the hotel, a hotel employee did fumigation (fogging) on the sixth floor where the workshops took place, and the reporters were not allowed to cover or take pictures [1].

Ex-lepers also often have difficulty in getting public services which include health, education, and public sector employment. One of them in terms of getting a job, which in Act No. 4 of 1997 on Persons with Disabilities, explained that from the total number of employees in a company, $1 \%$ should come from people with disabilities. However, the company is reluctant to accept disabled people, including ex-lepers as employees because the company argued that ex-lepers cannot 
work optimally. These conditions affect the ex-lepers who do not get decent job opportunities. Ex-leper is also a citizen of the Republic of Indonesia in the Act of 1945 Article 28, is guaranteed to have the status, rights, obligations, and roles which equal to other citizens. These conditions make the exlepers as subaltern groups in the social structure, the lower classes which experience oppression and discrimination to be marginalized.

To assert and maintain an identity as a subaltern group, exlepers can acquire, expand and maintain the identity as real evidence in the social representation so that they can be recognized and can put off the "clothes" minority. Therefore, the subaltern is closely related to the power of relations and politics. The position of the ex-lepers which are a minority and marginalized affects them to have a turning point to fight to seek their obsessions to be recognized and equalized through identity politics.

Identity politics is a "political action to place the importance of the members of the group as a priority because it has the same identity or characteristics, whether based on class, ethnicity, gender, or religion" [2]. Identity politics is another formulation of political differences. This is because identity is also about everything that makes a group of people to be different from others. Identity politics refers to political mechanisms of organizing the identity (both political identity and social identity) as a resource and political means ".

The emergence of identity politics is a response to the implementation of human rights which are often implemented unfairly. Disabled people of ex-lepers are one of the parties who become victims of injustice because people have classified that ex-lepers are not "normal". This prejudice is reflected also in the social and cultural life of society so that disabled people of ex-lepers are seen in disgust, horror, and joblessness.

The same conditions occurred in the Sumberglagah hamlet, the village which is called a leprosy village. They are ex-lepers who have been declared cured by Leprosy Hospital in Sumberglagah hamlet. After experiencing the process of treatment at the hospital and having been declared cured by doctors, the ex-lepers do not want to go back home to their hometown because of their disabilities. These disabilities make them feel insecure and excluded from the family and society, and as a result, they settled in Sumberglagah leprosy hamlet.

Since its founding, Sumberglagah hamlet is a reservoir of the ex-leper which is formed by the Social Service. Initially, there were only about 25 families and then continued to grow. Most of the ex-lepers who live in Sumberglagah leprosy hamlet are the lepers who spread around Surabaya and Mojokerto Street. In addition, there are also ex-lepers of Hospital Sumberglagah who are no longer accepted by the family and relatives. Then they chose to live in the Sumberglagah hamlet with other ex-lepers because they felt free and got closer to controlling their treatment.

Ex-lepers in Sumberglagah hamlet is a heterogeneous community, complex, and multi-identity. Identity variations of ex-lepers include the identity of the region of origin, culture, and employment. The complexity of ex-leper's identity is faced by the lack of recognition of identity which is equivalent to a normal person. Meanwhile, in the perspective of the public society, the ex-lepers are still considered to have a particular identity and still difficult to be aligned with each other. Society still considers that ex-lepers are still categorized as people with disabilities identity, disgusting, and contagious. Ex-lepers also struggle to obtain the rights and recognition of their identities and try to eliminate the stigma that exists in society.

Dealing with research conducted by I Gusti Putu Bachelor of "Society Treatment and Rehabilitation of Lepers and Exlepers in the village of Tegal Mengkeb, Abiansemal, and Lod Tunduh, Bali: An Anthropological Study of Health about Leprosy". Wrong beliefs and divergent cultural knowledge influence the society treatment of ex-lepers for instance, the ex-lepers are scorned and even ostracized and isolated from the social environment, including a ban following the customary and religious activities. Similar treatment was also subjected to the ex-lepers who are disabled.

Society's treatment of lepers and ex-lepers leads them to prefer living in their environment. It can be shown from the fact that many people with leprosy were declared cured medically but they still chose to reside in a leprosy environment, Yeh Putek. However, wherever lepers and exlepers reside, they always feel stress and depression. This condition is the result of the accumulation of the various sources of stress and depression such as knowledge and belief, customary and religious pressure, family and community treatments, the disease level, and the following characteristics. Meanwhile, As for the ex-lepers it was compounded by the presence of various old age diseases. Social rehabilitation cannot help much to reduce stress. Therefore, this study aims to identify the practice of identity politics carried out by exlepers in Sumberglagah hamlet, Mojokerto.

\section{METHOD}

This study used a qualitative method using a phenomenological approach of Alfred Schutz. This study took place in the Sumberglagah hamlet, Tanjung Kenongo, District Pacet, Mojokerto. Sumberglagah hamlet is a place to treat and rehabilitate ex-lepers and lepers through the Leprosy Hospital which was established there. About $60 \%$ population of Sumberglagah hamlet ever had leprosy therefore Sumberglagah hamlet is called leprosy village. Subjects were lepers who were elected through snowball sampling.

This study used two data collection techniques, primary data collection, and secondary data collection. The primary data were obtained through participating observation and interviews. While secondary data collections were obtained by searching books, articles, newspapers, and journals. This study uses inductive data analysis techniques and includes data reduction, display or data presentation, conclusions, and verification.

\section{RESULT AND DISSCUSION}

\subsection{Ex-leper Sumberglagah as subaltern groups}

Suffering from leprosy and then becoming ex-lepers, the citizens of Sumberglagah hamlet initially feel very embarrassed. Some of them even wanted to end their life as soon as possible and they were also abandoned by their families because they feel embarrassed to have the family of a leper. As experienced by Misdi, an ex-leper who works as a beggar.

"I was homeless and abandoned by parents because they were so ashamed to have a child who suffered from leprosy. It's worst, I was already considered dead and had already been 
prayed for 40 days. I knew about this because I met my Madurese friend when I worked as a beggar. Hearing the story made me stressed. Therefore I preferably live here, I have many friends and no more mockery ".

After recovering from leprosy, the ex-lepers who seek treatment in Leprosy Hospital Sumberglagah are majority reluctant to go back home. This is underlined because they feel shame within the family as well as neighbors and do not want to burden his family [5], so they decided to reside and settle in the Sumberglagah hamlet. According to ex-lepers, they already feel comfortable with the environment where they have the same fate and the weather is cool in mountainous areas. The skin of ex-lepers is sensitive when exposed to the heat of the sun. Consequently, Sumberglagah hamlet is full of ex-lepers and becomes a single entity in the leprosy village, Sumberglagah hamlet.

During the New Order, the ex-lepers received the full attention of the government. The government provided a program that provided basic needs for the ex-lepers or the lepers and the provision of a plot of land to build a home for ex-lepers who do not have any home or are homeless. However, now the situation is inverse, the government seems to have no care for the ex-lepers. Help does no longer exist, the ex-lepers are struggling with themself by looking for a job as anything. Ex-lepers majority work as farmers and farm workers and they even work as beggars to earn money for their family [6].

Ex-lepers in Sumberglagah hamlet experience various kinds of discrimination from the outside society. They still receive treatments that make it difficult to harmonize exlepers' rights with other societies, such as an experience that was experienced by Jariati.

"Poor Glagah citizens here, some citizens of neighbor village are fear with us but some of them are not, we have to treat every people differently because each of them is different. People who already know about leprosy will be friendly with us but they do not want to eat our food. Meanwhile, people who are not familiar with leprosy, so insult us, gossip about us, denounce us, as if they invite us to war. When I go shopping in the market, I should not buy on those who fear me, they fear that their customers will go, for they fear to me ".

To marry other citizens is an impossibility. People are afraid to marry their children with ex-lepers, they feel disgusted and afraid their children will have leprosy. So the ex-lepers in Sumberglagah marry their children with children of ex-lepers as well, and it can be concluded that former exlepers in the Sumberglagah hamlet are a whole family.

"No one wanted to marry me, I had proposed to three girls from three different villages, and the answer was, all the same, they were afraid to marry me because they were afraid to have children who have leprosy. It hurts me. Unexpectedly when I had a home here, I met Poniran, and immediately he offered me to marry his daughter. Soon I married his daughter, Rini. She also wanted to marry me. Thank God, now I already have two children, the first is still in 5th grade, and the second is 8 months old. The majority of people here married the children from here as well. So it can be said that we have one village, one family, one unity, and one destination ".

Stigma and discrimination which are developed in the society make the ex-lepers marginalized. The discrimination includes the difficulty in having a mate, a shame feeling of the children to have parents of ex-lepers, difficulties finding a job in a factory, and a lack of access to public facilities. Various discriminations experienced by exlepers in Sumberglagah hamlet occurred because the people around who are physically healthy and free of leprosy dominate over ex-lepers in Sumberglagah hamlet [7]. According to Spivak, ex-lepers are classified into a subaltern group, a group of people who are marginalized and executed in the public domain so that they are under pressure, particularly in the fight against the stigma of a healthy society who are dominant [6]. Although ex-lepers in Sumberglagah hamlet in isolated conditions, this group still has a fixed identity that they defend. Besides defending their identities, the group also seeks to maintain their existence as a group of ex-lepers.

Ex-leper in Sumberglagah hamlet is weakened as a result of the dominance of the society because of the stigma, so the presence of ex-lepers cannot get a decent place for the society. As a subaltern group, ex-lepers cannot express their aspirations, they can only be silent and have no ear for the elite to listen. Ex-lepers do not have space to voice their condition, so it needs the intellectuals as their "representatives" [7].

Poniran is the representative of ex-lepers in Sumberglagah hamlet. He is a brave figure and fights wholeheartedly and selflessly to get the rights of ex-lepers back. His fight against the stigma of the ex-lepers is seriously done to set them free from negative perception and stigma of society so that there is no discrimination for ex-leper and the identity of the ex-lepers can be accepted and recognized by society. the citizens of Sumberglagah particularly ex-lepers need representatives like Poniran that can voice the silenced voices of those who are truly oppressed so that the ex-lepers can express their aspirations and their condition to the public. As expressed by Sadi.

"When I knew Poniran for the first time, I felt amazed to him. He's a good person, not arrogant, and he made us feel that we were one entity. We were both struggling to build the village. If there is discrimination, Poniran always takes a role to solve it. For example, when there was a problem with the electronic ID card, Mr. Ran (Poniran) directly sabotaged or sealed the district. If Mr. Ran did not do it, no one wanted to hear our voices ".

Piran fights as speaking for the ex-lepers in Sumberglagah hamlet, he fights actively to defend the group of ex-lepers and voice what becomes their rights to be heard by the outside society even more by the government so that there is no longer a stigma, restrictions on citizenship rights and the loss of opportunity to express themselves.

\subsection{The identity politics practice of Sumberglagah ex-lepers}

In the past time, ex-lepers were active to follow the activities of the Indonesia Leprosy Foundation (ILF) and the Association of Independent Leprosy (AIL), but gradually they faced financial difficulty, and finally took the decision to try to fight for themselves. There was also the empowerment of ex-lepers, but it did not run so long, the difficulty of financial capital supply and the rarely buyers forced them to stop the empowerment activities.

The existence of discrimination from society to ex-lepers caused the ex-lepers marginalized from society. Ex-lepers 
form a group to fight for their rights together and fight the stigma that exists in society. Ex-lepers in Sumberglagah hamlet has been one entity, one family, one intention, one aim, and one fate. Friendly, fair, and helping each other are their characteristics. Currently, the citizens of Sumberglagah concentrate only within the scope of any village due to the limit of funds that they have and there is not any government help anymore. They also cannot set up a foundation because no donors who help them, such as identity politics expressed by Ismail.

"Instead of making a foundation or an organization, we, like lepers, get difficulty to do everything. There are not any donors therefore we get difficulty eating. Here we fight together as best as we could. if there is a counseling program, we are happy and enthusiastically follow it, by following such that program that there is an action or interaction then we can ask and answer with the public directly, but if there is only a seminar, we only meet the doctor and ex-lepers, if there is rarely action, we fight by ourselves ".

Ex-lepers carry out various ways to their identities. Although there is no agency or foundation support, they actively participate to defend and acquire their rights and omit society's discrimination against them. The practice of identity politics carried out by ex-lepers is as their resistance over the treatment of non-leprosy society. Resistance is shown in two forms [6] :

\section{Resistance Morality}

Slowly but surely the ex-lepers run several activities, including health education of lepers and ex-lepers in collaboration with health centers and Leprosy Hospital Sumberglagah, cooperation in every village activities, as well as recitation and istighosah regularly every Saturday. The head of Sumberglagah hamlet, Poniran, is a representative of ex-lepers in the seminar. Poniran talked and explained much about the elimination negative stigma of society towards exlepers. Through these activities, the public can hear the aspirations of ex-lepers. Their struggle was not useless and it obtained good results. It could be seen that more citizens know and understand ex-lepers after having health education with health center and Leprosy hospital.

There is not much that ex-lepers can do to set them free because their movement space is restricted. However, they are energetically trying to expand the movement space to be recognized and equalized with other societies. One of them is getting closer to God through regular religious activities and to socialize with other societies. Ex-lepers in Sumberglagah are trying to convince the outside society not to be rude and unfair to them because human beings have equal rights and there is nothing to distinguish each of them from God. Religious activities are carried out to control the emotions of ex-lepers, as it often happens anarchy demonstrations of exlepers to get the rights of public access.

Da'wah conducted by Mahmudin was able to make people aware of the importance of living in harmony among humans, there is no difference between them. it particularly happened to ex-lepers who fought to omit the stigma about them. Mahmud has already been trusted by people to be the speaker at religious activities or celebrations. Activities carried out by ex-lepers aim to create interaction and socialization between ex-lepers in Sumberglagah hamlet and the outside society. Not only conducting those kinds of activities, ex-lepers but also established relationships with other ex-lepers throughout
Indonesia through the Indonesian Leprosy Foundation (ILF) and the Association of Independent Leprosy (AIL) that exlepers had ever followed actively in Sumberglagah hamlet.

The practice of identity politics carried out by the ex-lepers in Sumberglagah hamlet is a moral resistance. Ex-lepers follow the activity by considering the norms and values in society as well as possible to be accepted, recognized, and equalize their existence with the other society. It is easier for them to socialize with society, to create a harmonious and peaceful life. Through these ways, their aspirations can be heard by the public [8].

\section{Radical Resistance}

Not only conducting the resistance of morality, but the exlepers in Hamlet Sumberglagah also conduct radical resistance. They are classified as more sensitive and temperament because they are often threatened unfairly. This is done as a rebuke over the stigma accepted and to make their presence noticed. As like what Poniran was done during the creation of electronic ID cards, Poniran and Sumberglagah citizens sabotaged and sealed the district office. Demonstrations were done because they received injustice in the public service. Sumberglagah citizens had a taking picture schedule at the midnight. It was already clear that they received very unfair treatment and made them very angry. Other radical actions were undertaken by ex-lepers, as expressed in Ismail below.

"Previously, minibusses were ever taken hostage twice by the Glagah (sumberglagah citizens). We were angry, we were not allowed to take the bus, and we were on foot from Mojosari to here. When I bought dawet(a traditional drink from Indonesia) in markets, the seller said that dawet had run out then I immediately stirred the pan with a hand so that no one bought dawet. "

Radical resistance is carried out as ex-lepers' strategy to convince people who oppose them. Facing public response which did not appreciate even deride the ex-lepers' fight makes the ex-lepers get angry and act radically to the dominant society. This is justified by Jariati as follows.

"It makes me think what the society wants out there. There are people who have already been familiar with the programs of lepers here, but also there are people who are provoking because they dislike. People who already know can receive the ex-lepers here, but people who still do not know try to make caos with Sumberglagah citizens. Some of them gave responses but some of them did not. The people in Sumberglagah do not take it as a matter anymore. The people here do not make any trouble but we are always harassed, as a result, we are getting angry. The most important is how the ex-lepers in Sumberglagah convince us that we are already healed and healthy, and do not contaminate anymore".

The struggle of ex-lepers in Sumberglagah hamlet is a real effort to fight against the dominance of the non-lepers. Mindset and negative stigma addressed to ex-lepers have raised the awareness to change the situation through various actions. Ex-lepers assert and maintain their identities as tangible evidence in the social representation so that they can be recognized and put off the "clothes" minority To make it easier, it is illustrated in the following chart [9]. 


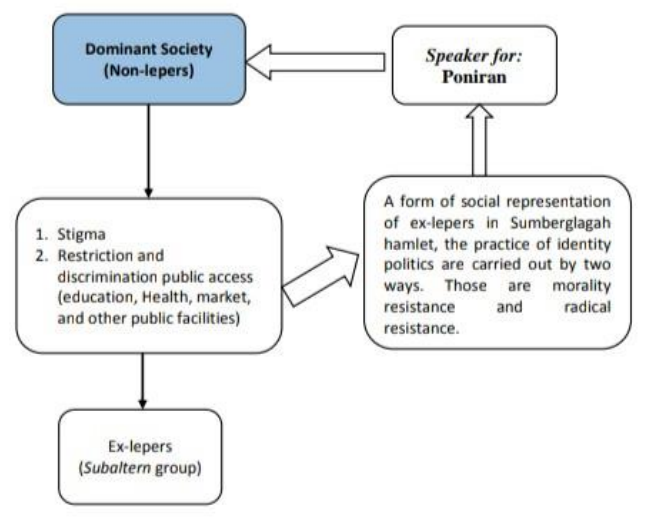

Figure 1. Chart Map Concept of Identity Politics carried out by Ex-Lepers

\section{CONCLUSION}

The condition of ex-lepers in Sumberglagah hamlet put them as a subaltern group, so they require a representative to voice their aspirations that can be heard by the public, including the government. In this case, speaking for ex-lepers actively plays a role to fight the rights of ex-lepers to achieve the goal to eliminate the stigma on former ex-lepers and equalize human rights to create a harmonious and peaceful life. Strengthening the identity of former ex-lepers in Sumberglagah hamlet is realized through morality and radical resistance. The practice of identity politics are carried out by the ex-lepers in Sumberglagah hamlet as tangible evidence to create equality of social representation

\section{REFERENCES}

[1] A. Aisyah, "Hotel di Makassar Larang Eks Penderita Kusta Gelar Acara.," (http://news.okezone.com/read/2007/11/19/1/61950/ hotel-di-makassar-larang-eks penderita-kusta-gelaracara. Diakses 18 Maret 2013)., 2007.

[2] I. Kirawan, "Politik Identitas Komunitas Homoseksual dalam Film Milk," Komunikator, vol. 2, no. 1, 2010.

[3] L. Gandhi, Teori Poskolonial: Upaya Meruntuhkan Hegemoni Barat (Penerjemah: Yuwan Wahyutri dan Nur Hamidah). Yogyakarta: Qalam, 2006.

[4] T. Widayanti, "Politik Subaltern: Pergulatan Identitas Waria,” Yogyakarta, 2009.

[5] O. Indow, A. Pongtiku, A. L. Rantetampang, dan A. Mallongi, "Profile Stigma of Leprosy Patients in Manokwari District Provinsi Papua Barat," Int. J. od Sci. Healthc. Res., vol. 4, no. 1, hal. 144-152, 2019.

[6] S. Gitte, L. Rewaria, V. Santaram, dan S. Jamil, "Descriptive Study of High Leprosy Endemic Pockets and Exploring Occurrence Factors of Multicase Families in the Village of Salaunikhurd of Chhattisgarh State," Int. J. Med. Public Heal., vol. 11, no. 2, hal. 113-117, 2021.
[7] S. Sermrittirong dan W. H. Van Brakel, "Stigma in leprosy: concepts, causes and determinants.," Lepr. Rev., vol. 85, no. 1, hal. 36-47, 2014.

[8] M. Bernstein, "Identity politics," Annu. Rev. Sociol., vol. 31, no. July 2005, hal. 47-74, 2005.

[9] H. Zhang, "Changing of Political Identities within the Globalization Context," Int. J. Soc. Sci. Humanit., vol. 4, no. 4, hal. 279-282, 2014. 